\title{
地すべクの挙動解析における写真測量の応用
}

\section{Application of Photogrammetry to Analysis of Landslide Behaviour}

\author{
吉澤 孝和, $\quad$ 西澤 茂高** \\ 三澤 敏雄, $*$ 根岸 六郎** \\ Norikazu YOSHIZAWA, Shigetaka NISHIZAWA \\ Toshio MISA WA, Rokurou NEGISHI
}

\begin{abstract}
Velocity, moving direction and spreading boundary of mass-movement are important factors for prevention and reduction planning of landslide disaster. Without surveying, there are no means to measure these factors. However, no field surveying is available when ground destruction by the landslide is violent and dangerous. To such a landslide suddenly occurred at Hirose district in the north-western part of Nagano city, photogrammetry was examined by flights on October 5 -th and 10-th in 1989. Landslide behaviour was analyzed by finding threedimensional displacements of tracing points on photographs taken by the two flights. Accuracy of the photogrammetry, error propagation to displacement vector of the tracing points, and landslide behaviour analysis by the vectors on projection planes were investigated. Applicability of the phtogrammetry to the analysis of sudden and violent landslide behaviour was demonstrated by these investigations.
\end{abstract}

\section{1. 地すべりと測量}

地すべりとは，斜面を構成する地山の内部において 力学的なバランスが何らかの原因によって破壊され, 地中に発生した破壊面を境としてそれよりも上側に存 在する斜面構成物質が重力の作用により連続的または 間欠的に比較的緩慢な速度で移動する現象である。

地すべり地においては，地表に亀裂や段差・隆起や 陷没・崩落や崩積などの変状が発生する。これがその 場所を利用している人間の生活や各種の構造物に対し
て重大な脅威と損害をもたらす。地すべりによる災害 を未然に防ぎ，あるいは災害を最小限にくいとめるた めには, 地すべりの挙動を正確かつ迅速に把握して適 切な対策を講ずることが必要である11。

表 1 は地すべり地において行なわれている各種の防 災対策と代表的な実施項目，およびそれらの対策に利 用されている測量と測量成果を要約したものである。

これらの中で地形測量は最も重要な地位を占めてき た。すなわち地すべりで発生した諸現象を地形の変遷 に注目して検討していくことが，地すべりの実態を把 握し，合理的な対策を講ずるうえでの必要不可欠の要

表 1 地すべり地における各種の対策と測量

\begin{tabular}{|c|c|c|}
\hline 対策の名称 & 主 要 実 施 項 目 & 利用される測量と成果 \\
\hline 避難・監視 & 警戒, 崩壊予知, 危険地域判別, 避難条件判定, 復旧後の監視 & 変位追跡, 地形図, 写真等 \\
\hline 制御・抑止 & 要因の分析と誘因の制御, 災害の波及領域の予測と拡大の抑止 & 地形・断画図, 変位, 写真 \\
\hline 復旧・保全 & 被災地の復旧, 再発防止工事, 諸施設の保全, 土地の利用規制 & 各種地形変遷図, 空中写真 \\
\hline
\end{tabular}

\footnotetext{
*信州大学工学部 **株式会社 協同測量社
}

「写真測量とリモートセンシング」Vol. 30,No. 5, 1991 
件であり，地形図は情報提供の最良の手段であった。 そのため，測量技術者が担当してきた従来の業務は， 地形に関する平面図や断面図の作成および空中写真の 提供にとどまり，地すべり対策に関連する解析や計画 に直接参加する機会は少なかった。

近年, 地すべり地において有望視されている測量は, 地表の諸点に対する三次元絶対変位の追跡であ $3^{\mathrm{C} 1)}$ 。トータルステーションの普及によってこの観測 手法は飛躍的に進歩した ${ }^{\mathrm{C} 2)}$ 。諸点の三次元変位データ を解析して，地すべりブロックの絶対移動量，移動方 向, 移動速度, 面積変化, 主Uずみ等が求められる ${ }^{2)}$ 。 さらにこのデータは, 崩壊時刻の予測 ${ }^{3)}$, 地下すべり面 形状の推定 ${ }^{4)}$, 地すべりの影響範囲の推定5)などにも利 用できる。したがってこれは測量技術者が地すべり対 策に直接関与することのできる応用測量の一部門とい える。

\section{2. 変位追跡と写真測量}

本研究は空中写真測量により, 地すべり挙動を迅速 かつ適切に解析し, 各種の対策に利用できる情報を提 供する手法を検討することを目的とする。地すべり地 に対する従来の写真測量は地形図の作成が主目的で あった。変位追跡への利用も試みられてきたが, それら は危険な活動期を過ぎた時点で対空標識を設置して長 期間にわたる緩慢な変位を検出し, 平面図や断面困上 における変位べクトル図を作成するものであった6)。 本研究はこれに加えてつぎの 3 点を検討する。

1）緊急時における早期情報提供技術の検討：危険 で立ち入りのできないような地すべり地に対する効果 的な緊急観測と解析手法を実験的に検討する。

2）変位追跡手法の能率化と精度の検討：地すべり 発生地に対空標識を設置せず, 地物を利用して変位を 追跡する手法とその精度を検討する。
3）地すべり影響範囲の早期把握：地すべりの影響 範囲を地物の変位検出によって迅速に把握する。

要するに本研究は, 活動が激しくて危険な状態の地 すべりに対して, 安全かつ迅速に観測を行ない得る手 段は空中写真測量のみであるという点に着目して, 地 すべりの早期診断と, 的確な対策を施すための防災情 報の提供手法を検討するものである ${ }^{\mathrm{C} 3)}$ 。

\section{3. 解析対象地域の概要}

本研究の対象として, 長野市広瀬地区の地すべりを 選んだ(図 5 参照)。1989年10月 3 日，長野市の広瀬地 区に地すべりが発生した。この日の午後, 農道直下の

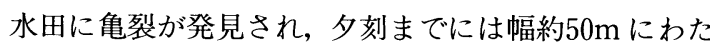
る断続的な馬蹄形状に成長した。この一帯は上部が水 田，下部が森林や雑草で覆われた斜面で，農道から約 $70 \mathrm{~m}$ 下方に谷川がある。谷の水流が地すべりの土砂で 堰き止められた場合，それの決壊による土石流災害を 懸念して，その日から直ちに監視体制がとられた。地 表の動きは当初かなり活発であったため, 現地でなし 得た計測は初日に設置した 3 基の伸縮計のみであり， 他の計測は立ち入りが危険のため行なわれなかった。 しかし10月 6 日までは活発な動きを見せていた地すべ りも，それ以後は急速に休止状態に入って現在に至っ ている。

\section{4. 地表目標物の三次元変位の計測と精度}

筆者らが地すべり発生の情報を得たのは翌10月 4 日 であった。これに本研究を試行することを考え，直ち に写真撮影の手配をして最初の撮影を 10 月 5 日15時 24 分に, 2 度目の撮影を 10 月10日14時22分に行なった。 この地すべりの活動期間からみると撮影の出足がやや 遅れた結果となった。しかし2 回の撮影で得られた写
C1）慣用的な従来の地すべり変位計測機器に伸縮計と傾斜 計がある。精度は測量の場合よりも $1 \sim 2$ 析高い。し かしこれらは地すべり地内の 2 点間の相対的な変位を 計測するのみであって, 地すべり土塊の移動方向や移 動の絶対量を検出することはできない。現在の計測技 術においてこれをなし得るのは測量のみである。

C2）地すべり地における地表の諸点の変位追跡は, トー夕 ルステーションの普及以前には, 見通し杭測量, トラ
バース測量，三角測量，水準測量，写真測量等で行な われてきた。これらの测量は主として変位の有無を検 出することを主眼としたものであり，解析的なものは 移動べクトル困の作成程度であっだ)。

C3）一般に地すべり地において地表の諸点の三次元変位を 追跡する場合, 精度や経費面で比較した場合には地上 測量によるトータルステーション方式のほうが有利で ある。しかし現地立入が不可能な地すべり地で, 迅速 


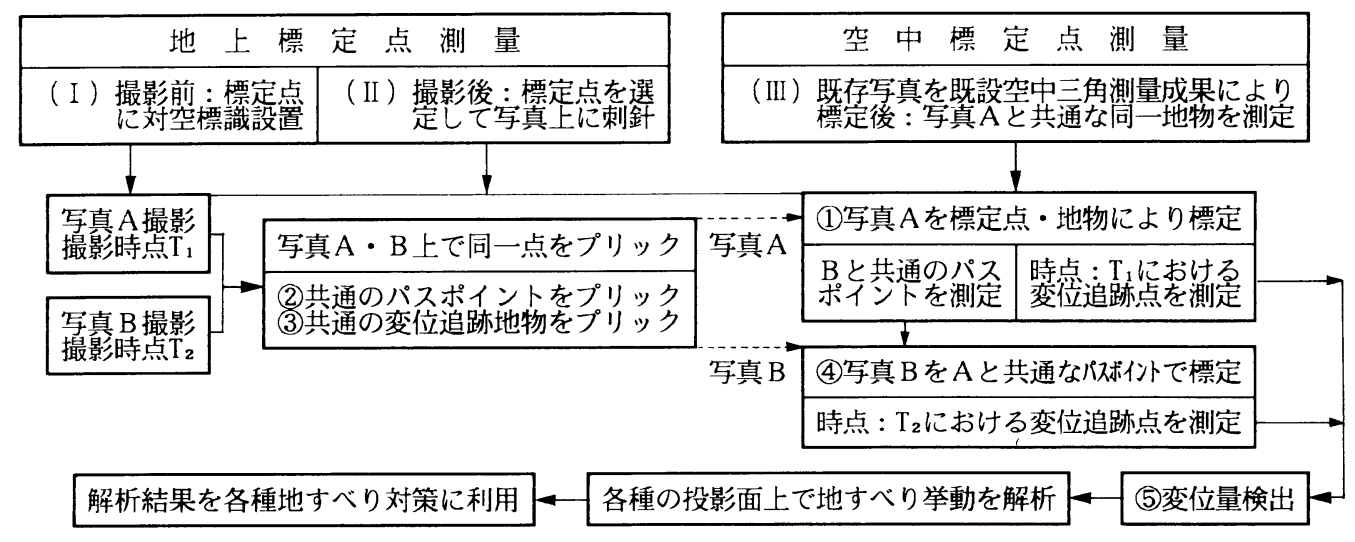

図 1 写真測量による地すべク挙動の追跡および解析の手法

真を対比した結果，第 2 章で述べた研究目的に利用で きるものと判断した。よってこの章では，撮影された 写真上で判別できる地物を利用した変位追跡の手法と その精度について検討する。

\section{4-1地すべり挙動追跡用の写真撮影}

図 1 に空中写真測量による地表変位の検出法と解析 の手順を示す。地すべりの発生という緊急事態の下で は，地すべりの動態を如何に迅速かつ正確に把握でき るかが問われる。最も重要なことは最初の撮影を一刻 も早く行なうことである。その理由は，地表の変位は 2 つの異なる時点で撮影した写真上の目標物の座標値 の差から検出され，その差が大きいほど，写真測量で 生ずる䛊差の影響が減少するためである。

\section{4-2 撮影写真の対地標定}

撮影写真の対地標定には図 1 の(III)の方式を用い た。この方式は既存の写真の空中三角測量成果を利用 するもので精度は低いけれども，時間的な余裕のない 緊急時の地すべり挙動の追跡には効果的な手法であ る。

本研究で準備した空中写真はつぎの 3 種類である。 写真O：過去に別の目的で空中三角測量を実施したこ とのある既存の空中写真（1984年 5 月 24 日撮影，カメ ラ : NAG II 7110，C=213.80mm，縮尺 1 / 8000) 写真A：今回の撮影写真（1989年10月 5 日撮影, カメ ラ：UAG I 6037, C=153.43mm，縮尺 $1 / 5600$ ) 写真B：今回の撮影写真 (1989年10月10日撮影, カメ ラ，縮尺は写真 $\mathrm{A}$ と同一)

対地標定はまず，解析図化機（DSR11）で既存の写 $-10-$
真Oを空中三角測量成果により標定したのち，今回の 写真Aの上でも明確に同一物と判定できる地物をパス ポイントとして 8 点選び，それらの座標を測定した。

本研究では対地標定で生ずる写真 $\mathrm{A} ， \mathrm{~B}$ 両モデルの 相対的な䛊差をできる限り小さくする必要があ $3^{(4)}$ 。よって写真 A， Bに共通のパスポイント（二次 のパスポイント）を新たに 8 点選点した（図1の(2)。 これらは，地すべり変動の影響が及ばない安定した場 所の明瞭度の高い地物を選定した。

二次のパスポイントの座標は，上記の写真Oに準拠 して写真Aの対地標定を完成させた後に測定した（図 1の(1)(4))。

\section{4-3＼cjkstart変位追跡点の選定とプリック}

変位追跡点は, 写真上に写し込まれた自然または人 工の地物で，写真Aと Bの上でそれが同一物であるこ とを明確に判定できることが必要である。本研究では 変位追跡点として：1）識別しやすい石や岩の角, 2）擁壁や道路上の目印，3）耕地の中の諸点（農作物 の境界点や点在する小物体)，4）水田の畦道の屈曲 点，5）雑草地の中の裸地の特殊形状，6）森林の中の 樹木の頂点などを選んだ。これらのうち，5）と6)は精 度的にみた場合不適当なものであるが，森林または雑 草におおわれた場所に対して，やむを得ず採用したも のである。

地すべりの発生している場所の地表形態は時間とと もに変化する。そのため撮影時点の異なる $\mathrm{A} と \mathrm{~B} の$ 写

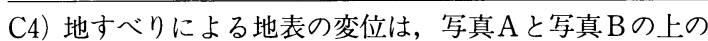
同一の地物の三次元座標值の差から検出される。 
真上で対空標識なしで同一地点を探すことは困難をき わめる。そこで本研究は A B 両写真上に共通する変位 追跡点を定めるために, 実体移写器 (PUG 4) を用い てタイポイント選点プリックの手法を応用した ${ }^{(5)}$ 。

まず PUG 4 に写真Aの左側と写真Bの右側のポジ フィルムをセットして実体視する。このとき地すべり の生じている場所では実体像がくずれるが, 破壊や変 形の生じていない部分では同一の地物像は重なり合っ て局部的に実体視ができる。この原理を用いて写真像 の拡大率を 20 倍前後で統一し, 目標物を部分ごとに実 体視しながら，視差を完全に消去して両フィルム上に 同一の変位追跡点を定めてプリックした（図1の(3)。

変位追跡点は, 地すべり地内とその周辺になるべく 均等になるように，また地表変状の激しい亀裂や段差 の付近を避けて，57個の点を選点してプリックした。

\section{4-4 变位追跡点の測定精度}

本研究では対空標識のかわりに地物を利用し，さら に二次的な標定作業を繰り返して変位追跡点の座標を 求めている(図 1 の(1)(4))。そのため通常の機械的誤差 に加え, 作業工程に伴う移写の䛊差, 標定の誤差, お よび測定の誤差が累積する。本文では以下に示すよう に，これらの誤差に関する検討を実験的に行った。

\section{A）移写と座標測定の精度に関する検討}

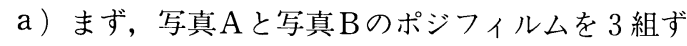
つ複製した。これを写真対 A1，A2，A3，B1，B2，B3 と呼ぶ。

b) 写真対 A1の左側写真に対して順次，写真対 B1，B2，B3の右側写真を組み合わせ，二次のパスポイ ントおよび, 上記4-3の手法でフィルム上に変位追跡点 を定めてプリックした。以下これをプリック点と呼ぶ。

c）写真対 A1の左側写真上のプリック点を, 写真 対 A2およびA3の左側フィルム上に移写した。

d）各フィルム上の個々のプリック点の座標をステ

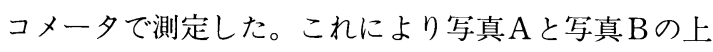
の個々のプリック点の座標測定值は 3 個ずつ得られ る。

e ）写真 A B 上の各プリック点の 3 個の座標測定值 の平均值を求め, 座標測定值の残差を次式で計算し た：

(残差 $\mathrm{v})=($ 座標测定值 $)-($ 座標平均值 $)$

f ）ここでプリック点を次の 4 種類に大別する： ・標定点（4-2で述べた 8 個の二次のパスポイント）
·地表点（4-3の 1)，2），3），4）に該当する地表の 明瞭な変位追跡点で40点を選点)

・荒地点（前記4-3の 5 ）に該当する点で 6 点を選点） ・樹上点（前記4-3の 6) に該当する点で11点を選点） これらの種類別に, プリックと座標測定の過程でど の程度の残差が生ずるかを検討してみる。ひとつの指 標として, 式(1)で得られる残差を点の種類別にみたと きの平均と変動を次のように定義した：

$$
\begin{aligned}
& (\text { 残差平均 })=\Sigma|v| / n \quad(\mathrm{n}=\text { デー夕数 }) \\
& (\text { 残差変動 })=\left\{\Sigma \mathrm{v}^{2} / \mathrm{n}(\mathrm{n}-1)\right\}^{1 / 2}
\end{aligned}
$$

写真 $\mathrm{A}$ と写真 $\mathrm{B}$ について行なった解析結果を表 2 と 表 3 に示す。

表 2 プリック点の残差の検討 (写真A)

\begin{tabular}{|c|cc|}
\hline \multicolumn{4}{|c|}{ (残差平均) \pm (残差変動) [単位 $: \mu]$} \\
\hline 標定点 ( 24$)$ & $2.83 \pm 0.34$ & $5.17 \pm 0.74$ \\
地表点 (120) & $2.88 \pm 0.19$ & $5.30 \pm 0.32$ \\
荒地点 ( 18$)$ & $2.94 \pm 0.54$ & $5.50 \pm 0.76$ \\
樹上点 ( 33$)$ & $3.03 \pm 0.53$ & $6.67 \pm 0.64$ \\
\hline
\end{tabular}

\begin{tabular}{|c|c|c|}
\hline 測点 (データ数) & $\mathrm{X}$ 座 標 & $\mathrm{Y}$ 座 標 \\
\hline 標定点（ 24） & $4.46 \pm 0.47$ & $3.42 \pm 0.59$ \\
\hline 地表点（120） & $9.52 \pm 0.70$ & $14.93 \pm 0.97$ \\
\hline 荒地点（ 18） & $7.17 \pm 1.69$ & $14.11 \pm 2.50$ \\
\hline 樹上点（ 33） & $12.72 \pm 1.76$ & $17.97 \pm 3.33$ \\
\hline
\end{tabular}

表 3 プリック点の残差の検討（写真 B)

表 2 と表 3 の数值は, フィルムの歪, プリック作業 および座標測定作業の誤差が総合されたものである。 これらの表からつぎの考察がなされる。

(a) 標定点の誤差は写真 $\mathrm{A}, \mathrm{B}$ とほぼ同程度である。

C5）これが本研究における地すべりの地表変位計測手法の 特長である。地すべり変位の検出に関する従来の写真 測量の手法は, 対空標識を蜜に設置して地表変位を検 出する手法6 と地すべり災害前後の空中写真から同一 地物を判別して移動量を求める手法帛に大別される。 前者は緩慢な地すべりを对象とした長期間にわたる計 測手法で精度は高い。後者は災害調查的なもので 10 数 $10 \mathrm{~m} の$ 移動量を検出するが精度は低い。本研究 では移動速度に関係なく進行中の地すべりを対象と し，对空標識を用いずに地物を利用する。そして変位 検出の精度をできるだけ高く保つことを目的としてこ のような手法を試みた。 
これらは変位追跡点（地表点・荒地点・樹上点）の 誤差よりも小さい。これは標定点を地すべり地から 離れた明瞭な舗装路面上に選んだためである。

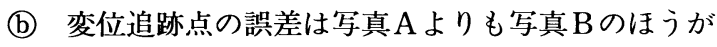
かなり大きく生じている。これは前記 b)，c）に示 したプリックの手順の相違に起因するものであり, 本研究の手法から見た場合, やむを得ないことであ る。

(C) 写真Aでは, 地表点, 荒地点, 樹上点の順に誤差 が増加している。これは目標とした地物の性質から 見て当然の結果と言える。

(d) 写真Bでは荒地点よりも地表点の誤差のほうが大 きくなった。これは前記 b ）の手順において, 個々 の変位追跡点を実体視によってプリックする回数 が, 荒地点（デー夕数18）に対して地表点（デー夕 数120)のほうがはるかに多く, 個々の変位追跡点の 移写の際に生ずる誤差の累積に起因するのと考えら れる。

(e) 樹上点の誤差は写真 $\mathrm{A}, \mathrm{B}$ とも他の測点の誤差よ クも大きい。これは目標点の位置的な不安定性によ るものである。

\section{B）標定および座標測定誤差に関する検討}

解析図化機 (DSR11)を用いて，写真A，B上で個々 の変位追跡点の三次元座標值 $(\mathrm{X}, \mathrm{Y}, \mathrm{H})$ を求めた。 この座標值にはプリック，標定，計測という一連の 作業の過程で介入する䛊差が集積している。これを検 討するため, 次の手順で実験を行なった。

a ） A1，A2，A3およびB1，B2，B3の各モデルにつ いて対地標定を 2 回くり返す。

b ） 1 回の対地標定ごとに個々の変位追跡点の測定 を 2 回くり返す。

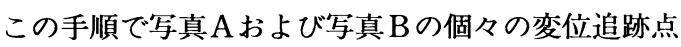
に対して ( 3 モデル $) \times(2$ 回標定 $) \times(2$ 回測定 $)=(12$ 個）の三次元座標デー夕が得られた。
つぎに $\mathrm{A}, \mathrm{B}$ 両写真上の各変位追跡点に対する三次 元座標の平均值を求め, 個々の座標值との差を残差と して平均二乗䛊差 $(\mathrm{m})$ を次式で計算した。 $\mathrm{m}=\left\{\Sigma(\text { 残差 })^{2} /(\mathrm{n}(\mathrm{n}-1))\right\}^{1 / 2} \quad(\mathrm{n}=12)$

ここで, 座標値の精度を変位追跡点の種類別に比較 するひとつの指標として, 各変位追跡点について得ら れた三次元座標の平均二乗誤差 $\left(\mathrm{m}_{\mathrm{XA}}, \mathrm{m}_{\mathrm{YA}}, \cdots, \mathrm{m}_{\mathrm{HB}}\right)$ を用いてつぎの量を求めた：

$(\mathrm{m}$ の平均 $)=\mathrm{W}=\Sigma \mathrm{m} / \mathrm{N} \quad(\mathrm{N}$ は測点数 $)$

$(\mathrm{m}$ の変動 $)=\left\{\mathrm{\Sigma}(\mathrm{m}-\mathrm{W})^{2} /(\mathrm{N}(\mathrm{N}-1))\right\}^{1 / 2}$

ここに $\mathrm{N} は$ 種類別にみた変位追跡点の数で，地表点は

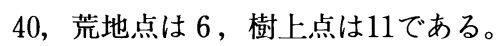

表 4 は変位追跡点の種類別に (m の平均) と（mの 変動）を求めたものである。この表からつぎの考察が できる。

(a) 平面位置の䛊差 $\left(m_{x}, m_{Y}\right)$ は写真 $A$ りも写真 $\mathrm{B}$ のほうが大きい。

(b) 標高の誤差 $\left(\mathrm{m}_{\mathrm{H}}\right)$ は写真 $\mathrm{A}$ と Bの間で大差ない。

(C) 変位追跡点全体を通じて, 標高の誤差のほうが平 面位置の誤差よりもかなり大きくなる。この傾向は 地表点, 荒地点, 樹上点の順に顕著となっていく。

(d) 平面位置の誤差を見ると, 地表点と荒地点との間 で大差は認められない。

(e) 樹上点の誤差は，写真 $\mathrm{A}, \mathrm{B}$ ともに最も大きい。

\section{5. 変位追跡点を用いた地すべり挙動の解析}

撮影時刻の異なる空中写真を用いて変位追跡点の座 標値を測定した場合，同一測点の座標値に座標差が認 められ，それが測量䛊差を十分上回るものであれば， その点は移動していると判定できる。よってこの座標 差から各点の変位べクトルを求め（図 1の(5) これを 各種の地すべり解析に利用することができる。

以下の検討では写真上の変位追跡点の座標値は, 多

\section{表 4 種類別に見た変位追跡点の座標値の平均二乗誤差 $\mathrm{m} の$ 比較}

\begin{tabular}{|c|c|c|c|c|c|c|}
\hline \multirow{2}{*}{ 測 点 (点数) } & \multicolumn{3}{|c|}{ 写 } & \multicolumn{3}{|c|}{ 写 } \\
\hline & $\mathrm{m}_{\mathrm{x}}$ & $\mathrm{m}_{\mathrm{Y}}$ & $\mathrm{m}_{\mathrm{H}}$ & $\mathrm{m}_{\mathrm{x}}$ & $\mathrm{m}_{\mathrm{Y}}$ & $\mathrm{m}_{\mathrm{H}}$ \\
\hline 地 表 点 (40) & $1.15 \pm 0.06$ & $0.67 \pm 0.03$ & $2.97 \pm 0.15$ & $3.09 \pm 0.19$ & $1.81 \pm 0.12$ & $2.94 \pm 0.18$ \\
\hline 荒 地 点（6） & $1.09 \pm 0.11$ & $1.13 \pm 0.13$ & $6.13 \pm 1.11$ & $3.24 \pm 0.48$ & $2.13 \pm 0.11$ & $6.55 \pm 0.75$ \\
\hline 樹 上 点（11） & $1.51 \pm 0.12$ & $1.81 \pm 0.24$ & $12.39 \pm 1.83$ & $3.93 \pm 0.76$ & $4.04 \pm 0.53$ & $10.59 \pm 1.64$ \\
\hline 全 測 点 (57) & $1.21 \pm 0.05$ & $0.94 \pm 0.08$ & $5.12 \pm 0.65$ & $3.27 \pm 0.23$ & $2.27 \pm 0.18$ & $4.79 \pm 0.56$ \\
\hline
\end{tabular}


数回の観測 (4-4-B) によってその平均值と平均二乗誤 差が与えられているものとする。すなわち, 撮影時点 $\mathrm{T}_{1}$ と $\mathrm{T}_{2} の$ 写真上で測定したひとつの変位追跡点の座 標の平均値と平均二乗誤差を次の記号であらわす：

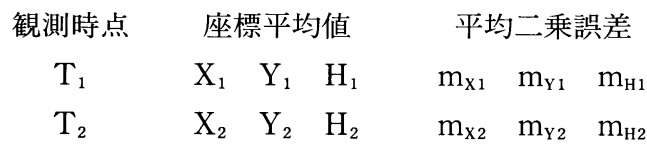

$\mathrm{T}_{1}$ から $\mathrm{T}_{2}$ の間に生じた座標差を次式であらわす：

$\Delta \mathrm{X}=\mathrm{X}_{2}-\mathrm{X}_{1} \quad \Delta \mathrm{Y}=\mathrm{Y}_{2}-\mathrm{Y}_{1} \quad \Delta \mathrm{H}=\mathrm{H}_{2}-\mathrm{H}_{1}$

この座標差を用いて以下の諸量を定義する：

三次元移動量 $: \mathrm{S}=\left(\Delta \mathrm{X}^{2}+\Delta \mathrm{Y}^{2}+\Delta \mathrm{H}^{2}\right)^{1 / 2}$

二次元移動量 : $\left\{\begin{array}{l}\mathrm{S}_{\mathrm{XY}}=\left(\Delta \mathrm{X}^{2}+\Delta \mathrm{Y}^{2}\right)^{1 / 2} \\ \mathrm{~S}_{\mathrm{XH}}=\left(\Delta \mathrm{X}^{2}+\Delta \mathrm{H}^{2}\right)^{1 / 2} \\ \mathrm{~S}_{\mathrm{YH}}=\left(\Delta \mathrm{Y}^{2}+\Delta \mathrm{H}^{2}\right)^{1 / 2}\end{array}\right\}$
三次元移動方向余弦 : $\left\{\begin{array}{l}C_{X}=\Delta X / S \\ C_{Y}=\Delta Y / S \\ C_{H}=\Delta H / S\end{array}\right\}$

二次元移動方向余弦：

$$
\left\{\begin{array}{ll}
\mathrm{C}_{\mathrm{XY}}=\Delta \mathrm{X} / \mathrm{S}_{\mathrm{XY}}, & \mathrm{C}_{\mathrm{YX}}=\Delta \mathrm{Y} / \mathrm{S}_{\mathrm{XY}} \\
\mathrm{C}_{\mathrm{XH}}=\Delta \mathrm{X} / \mathrm{S}_{\mathrm{XH}}, & \mathrm{C}_{\mathrm{HX}}=\Delta \mathrm{H} / \mathrm{S}_{\mathrm{XH}} \\
\mathrm{C}_{\mathrm{YH}}=\Delta \mathrm{Y} / \mathrm{S}_{\mathrm{YH}}, & \mathrm{C}_{\mathrm{HY}}=\Delta \mathrm{H} / \mathrm{S}_{\mathrm{YH}}
\end{array}\right\}
$$

\section{5-1＼cjkstart移動ベクトルに対する測量誤差の影響}

変位追跡点の移動量と移動方向を上の各式で計算し た場合, 座標值の誤差 $\left(\mathrm{m}_{\mathrm{x} 1}, \mathrm{~m}_{\mathrm{Y} 1}, \mathrm{~m}_{\mathrm{H} 1}, \mathrm{~m}_{\mathrm{x} 2}, \mathrm{~m}_{\mathrm{Y} 2}\right.$, $\mathrm{m}_{\mathrm{H} 2}$ ）がどのように影響するかを誤差伝播の法則に よって数式化した。その結果を以下に示す。

a ) 三次元移動量 $(\mathrm{S})$ に生ずる䛊差 $\left(\mathrm{M}_{\mathrm{s}}\right)$ :

$\mathrm{M}_{\mathrm{s}}{ }^{2}=\left\{\Delta \mathrm{X}^{2}, \Delta \mathrm{Y}^{2}, \Delta \mathrm{H}^{2}\right\}^{\mathrm{T}} \cdot\left\{\left(\mathrm{m}_{\mathrm{x} 1}{ }^{2}+\mathrm{m}_{\mathrm{X} 2}{ }^{2}\right),\left(\mathrm{m}_{\mathrm{Y} 1}{ }^{2}+\mathrm{m}_{\mathrm{Y} 2}{ }^{2}\right), \quad\left(\mathrm{m}_{\mathrm{H} 1}{ }^{2}+\mathrm{m}_{\mathrm{H} 2}{ }^{2}\right)\right\} / \mathrm{S}^{2}$

\{ \} は列べクトル，\{ $\}^{\mathrm{T}}$ は行べクトルである。

b ) 二次元移動量 $\left(\mathrm{S}_{\mathrm{XY}}, \mathrm{S}_{\mathrm{XH}}, \mathrm{S}_{\mathrm{YH}}\right)$ に生ずる誤差 $\left(\mathrm{M}_{\mathrm{SXY}}, \mathrm{M}_{\mathrm{SXH}}, \mathrm{R}_{\mathrm{SYH}}\right)$ :

$$
\left[\begin{array}{l}
\mathrm{M}_{\mathrm{SXY}^{2}}{ }^{2} \\
\mathrm{M}_{\mathrm{SXH}^{2}}{ }^{2} \mathrm{M}_{\mathrm{SYH}}{ }^{2}
\end{array}\right]=\left[\begin{array}{ccc}
1 / \mathrm{S}_{\mathrm{XY}^{2}} & 0 & 0 \\
0 & 1 / \mathrm{S}_{\mathrm{XH}}{ }^{2} & 0 \\
0 & 0 & 1 / \mathrm{S}_{\mathrm{YH}}{ }^{2}
\end{array}\right]\left[\begin{array}{ccc}
\Delta \mathrm{X}^{2} & \Delta \mathrm{Y}^{2} & 0 \\
\Delta \mathrm{X}^{2} & 0 & \Delta \mathrm{H}^{2} \\
0 & \Delta \mathrm{Y}^{2} & \Delta \mathrm{H}^{2}
\end{array}\right]\left[\begin{array}{c}
\mathrm{m}_{\mathrm{X} 1}{ }^{2}+\mathrm{m}_{\mathrm{X} 2}{ }^{2} \\
\mathrm{~m}_{\mathrm{Y} 1}{ }^{2}+\mathrm{m}_{\mathrm{Y} 2}{ }^{2} \\
\mathrm{~m}_{\mathrm{H} 1}{ }^{2}+\mathrm{m}_{\mathrm{H} 2}{ }^{2}
\end{array}\right]
$$

c ) 三次元移動方向余弦 $\left(\mathrm{C}_{\mathrm{x}}, \mathrm{C}_{\mathrm{Y}}, \mathrm{C}_{\mathrm{H}}\right)$ に生ずる誤差 $\left(\mathrm{M}_{\mathrm{CX}}, \mathrm{M}_{\mathrm{CY}}, \mathrm{M}_{\mathrm{CH}}\right)$ :

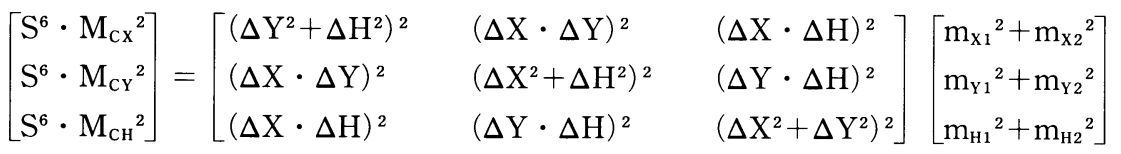

$\mathrm{d})$ 二次元移動方向余弦 $\left(\mathrm{C}_{\mathrm{XY}}, \mathrm{C}_{\mathrm{YX}}, \mathrm{C}_{\mathrm{XH}}, \mathrm{C}_{\mathrm{HX}}, \mathrm{C}_{\mathrm{YH}}, \mathrm{C}_{\mathrm{HY}}\right)$ に生ずる誤差 $\left(\mathrm{M}_{\mathrm{CXY}}, \mathrm{M}_{\mathrm{CYX}}, \mathrm{M}_{\mathrm{CXH}}, \mathrm{M}_{\mathrm{CHX}}, \mathrm{M}_{\mathrm{CYH}}\right.$, $\mathrm{M}_{\mathrm{CHY}}$ )

$\left[\begin{array}{l}\mathrm{S}_{\mathrm{XY}}{ }^{6} \cdot \mathrm{M}_{\mathrm{CXY}^{2}}{ }^{2} \\ \mathrm{~S}_{\mathrm{XY}}{ }^{6} \cdot \mathrm{M}_{\mathrm{CYX}^{2}} \\ \mathrm{~S}_{\mathrm{XH}}{ }^{6} \cdot \mathrm{M}_{\mathrm{CXH}^{2}} \mathrm{~S}_{\mathrm{XH}^{6} \cdot \mathrm{M}_{\mathrm{CHX}}{ }^{2}} \\ \mathrm{~S}_{\mathrm{YH}}{ }^{6} \cdot \mathrm{M}_{\mathrm{CYH}}{ }^{2} \\ \mathrm{~S}_{\mathrm{YH}}{ }^{6} \cdot \mathrm{M}_{\mathrm{CHY}}{ }^{2}\end{array}\right]=\left[\begin{array}{cc}\Delta \mathrm{Y}^{4} & (\Delta \mathrm{X} \cdot \Delta \mathrm{Y})^{2} \\ (\Delta \mathrm{X} \cdot \Delta \mathrm{Y})^{2} & \Delta \mathrm{X}^{4} \\ \Delta \mathrm{H}^{4} & 0 \\ (\Delta \mathrm{X} \cdot \Delta \mathrm{H})^{2} & 0 \\ 0 & \Delta \mathrm{H}^{4} \\ 0 & (\Delta \mathrm{Y} \cdot \Delta \mathrm{H})^{2}\end{array}\right.$

\section{5-2＼cjkstart誤差を考虑した移動ベクトルの表示法}

本文では変位追跡点の移動べクトルを，各種の投影 面（水平面または任意方向の鉛直面）の上に投影して 解析を行なう。この場合，前節で述べたような測点の 座標誤差の影響を考慮したべクトルの表示法が必要と なる。以下にその手法を示す。

図 2 において $\left[\mathrm{i}_{1}\right],\left[\mathrm{i}_{2}\right]$ は時点 $\mathrm{T}_{1}, \mathrm{~T}_{2}$ における変 位追跡点の座標平均値をプロットした点である。2 点

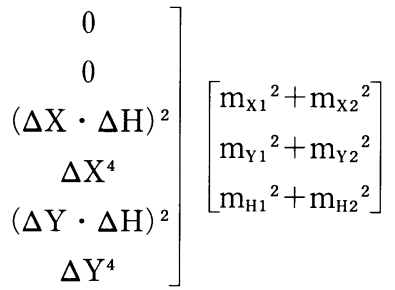

を結ぶと平均移動べクトルが得られる。図に示すよう にこのベクトルと平行な方向に $\mathrm{V}$ 軸を，直交する方向 にU軸をとる。ここで測定した座標の平均值と平均二 乗誤差をつぎの記号であらわす。

点 時点 座標平均值 平均二乗誤差

$\left[\begin{array}{llllllll}\left.\mathrm{i}_{1}\right] & \mathrm{T}_{1} & \mathrm{X}_{\mathrm{i} 1} & \mathrm{Y}_{\mathrm{i} 1} & \mathrm{H}_{\mathrm{i} 1} & \mathrm{~m}_{\mathrm{X} 11} & \mathrm{~m}_{\mathrm{Y} 11} & \mathrm{~m}_{\mathrm{H} 11}\end{array}\right.$ $\left[\begin{array}{llllllll}\mathrm{i}_{2} & \mathrm{~T}_{2} & \mathrm{X}_{12} & \mathrm{Y}_{12} & \mathrm{H}_{\mathrm{i} 2} & \mathrm{~m}_{\mathrm{x} 12} & \mathrm{~m}_{\mathrm{Y} 12} & \mathrm{~m}_{\mathrm{H} 12}\end{array}\right.$ 図の $\mathrm{Y}$ 軸と $\mathrm{V}$ 軸とのなす角 $\theta$ は次式で求められる。 
$\theta=\tan ^{-1}\left(\mathrm{X}_{12}-\mathrm{X}_{11}\right) /\left(\mathrm{Y}_{12}-\mathrm{Y}_{11}\right)$

$\mathrm{XY}$ 座標系から UV 座標系への座標変換は次式で行 なわれる。

$\left[\begin{array}{l}\mathrm{U} \\ \mathrm{V}\end{array}\right]_{\text {it }}=\left[\begin{array}{rr}\cos \theta & -\sin \theta \\ \sin \theta & \cos \theta\end{array}\right]^{\mathrm{X}}{ }_{\mathrm{it}(\mathrm{t}=1,2)}$

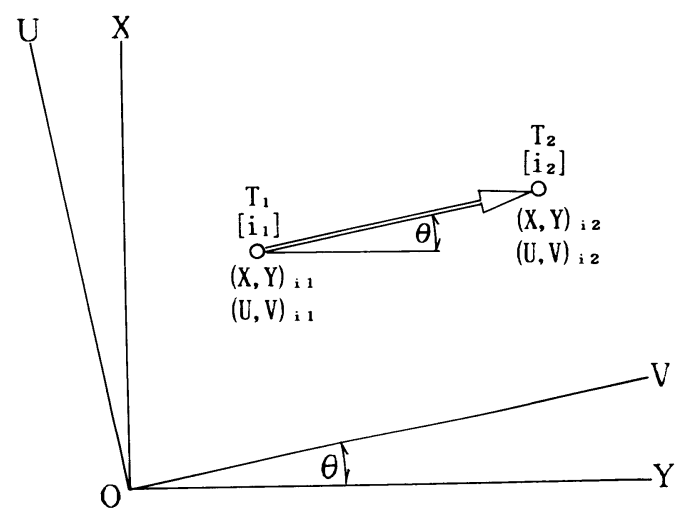

図 2 測点 $[\mathrm{i}$ ]

時間 $\mathrm{T}_{1} \sim \mathrm{T}_{2}$ における移動量の成分を UV 座標であ らわすとつぎのようになる。

$$
\Delta \mathrm{U}_{\mathrm{i}}=\mathrm{U}_{12}-\mathrm{U}_{\mathrm{i} 1}=0 \quad \Delta \mathrm{V}_{\mathrm{i}}=\mathrm{V}_{\mathrm{i} 2}-\mathrm{V}_{11}
$$

式(17)の座標変換によって座標值 $(\mathrm{U}, \mathrm{V})$ に伝播する 誤差 $\left(m_{U i t}, m_{V i t(t=1,2)}\right)$ はつぎのようになる。

$\left[\begin{array}{l}\mathrm{m}_{\mathrm{Uit}}{ }^{2} \\ \mathrm{~m}_{\mathrm{Vit}}{ }^{2}\end{array}\right]=\left[\begin{array}{ll}\cos ^{2} \theta & \sin ^{2} \theta \\ \sin ^{2} \theta & \cos ^{2} \theta\end{array}\right]\left[\begin{array}{l}\mathrm{m}_{\mathrm{Xit}}{ }^{2} \\ \mathrm{~m}_{\mathrm{Yit}}{ }^{2}\end{array}\right]$

変位追跡点 $[\mathrm{i}]$ の水平移動量に生ずる誤差を UV 座標系であらわすためには, 式(13)の第 1 行式を用いて, XをUに，YをVに読みかえればよい。これによって 次式が得られる。

$\mathrm{M}_{\mathrm{SUVi}}{ }^{2}=\mathrm{m}_{\mathrm{V} 11}{ }^{2}+\mathrm{m}_{\mathrm{Vi} 2}{ }^{2}$

同様の手順で，移動方向に生ずる䛊差は式(15)の第 1 行式から次のように導かれる。

$$
\mathrm{M}_{\mathrm{CUVi}}{ }^{2}=\left(\mathrm{m}_{\mathrm{U} 11}{ }^{2}+\mathrm{m}_{\mathrm{U} 12}{ }^{2}\right) / \Delta \mathrm{V}_{\mathrm{i}}{ }^{2}
$$

つぎにこのような誤差を含む変位追跡点 $[\mathrm{i}]$ のべク トルを図示する手法を述べる。困 3 は点 $\left[\mathrm{i}_{1}\right]$ を基準と してべクトルの誤差領域を示した概念困である。

(a)図において，座標平均值 $(\mathrm{X}, \mathrm{Y})_{\mathrm{i} 1}$ と $(\mathrm{X}, \mathrm{Y})_{\mathrm{i} 2}$ を 用いてプロットした 2 点 $\left[\mathrm{i}_{1}\right]$ と $\left[\mathrm{i}_{2}\right]$ を結べば，変位 追跡点 $[\mathrm{i}]$ の平均移動ベクトルが図示される。このべ クトルの長さには土 $\mathrm{M}_{\mathrm{Suvi}}$ の, ベクトルの方向には土 $\mathrm{M}_{\mathrm{CUVi}}$ の誤差が含まれる。そのためべクトルの始点を $\left[\mathrm{i}_{1}\right]$ としたとき, ベクトルの終点は困の a b c d で囲
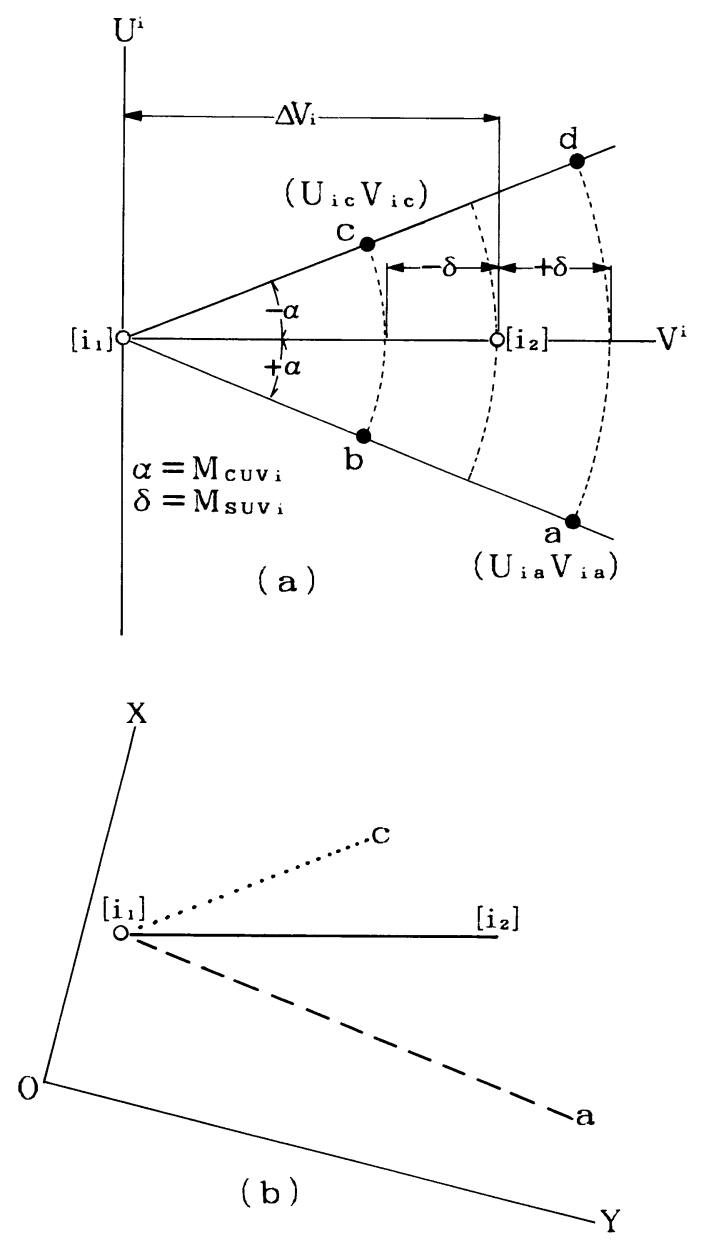

図 3 移動ベクトルの誤差領域と表示法

まれる扇形の中の 1 点となる。

本文ではこのような誤差を考えた場合のべクトルの 両極端の位置として $\mathrm{a}$ 点と $\mathrm{c}$ 点を考える。これらの点 の座標値は, UV 座標系では次のように与えられる。

$\mathrm{a}$ 点の座標值 $\left(\mathrm{U}_{1 \mathrm{a}} \mathrm{V}_{\mathrm{ia}}\right)$ :

$\mathrm{U}_{\mathrm{ia}}=\mathrm{U}_{\mathrm{i} 1}-\left(\Delta \mathrm{V}_{\mathrm{i}}+\delta\right) \sin \alpha$

$\left.\mathrm{V}_{\mathrm{ia}}=\mathrm{V}_{11}+\left(\Delta \mathrm{V}_{\mathrm{i}}+\delta\right) \cos \alpha\right)$

$\mathrm{c}$ 点の座標値 $\left(\mathrm{U}_{\mathrm{ic}} \mathrm{V}_{\mathrm{ic}}\right)$ :

$\mathrm{U}_{\mathrm{ic}}=\mathrm{U}_{\mathrm{i} 1}+\left(\Delta \mathrm{V}_{\mathrm{i}}-\delta\right) \sin \boldsymbol{\alpha}$

$\left.\mathrm{V}_{\mathrm{ic}}=\mathrm{V}_{\mathrm{i} 1}+\left(\Delta \mathrm{V}_{\mathrm{i}}-\delta\right) \cos \alpha\right)$

ここに $\mathrm{M}_{\mathrm{SUVi}}=\delta, \mathrm{M}_{\mathrm{CUV1}}=\alpha$ と略記した。

$\mathrm{UV}$ 座標系は個々の変位追跡点ごとに，ある時間帯 における平均移動方向を基準として定めたものである から，移動べクトルの図化にあたっては座標值（U, V）をXY 座標系の座標値に変換する必要がある。こ の変換は式(17)の逆変換で，次式を用いればよい。 


$$
\left[\begin{array}{l}
\mathrm{X} \\
\mathrm{Y}
\end{array}\right]=\left[\begin{array}{cc}
\cos \theta & \sin \theta \\
-\sin \theta & \cos \theta
\end{array}\right]\left[\begin{array}{l}
\mathrm{U} \\
\mathrm{V}
\end{array}\right]
$$

上式により点 $\left[i_{1}\right],\left[i_{2}\right], a, c$ 座標值を XY 座 標系の值に変換し，各点をプロットして(b)眓に示すよ うに表示する。ベクトルの起点を時点 $\mathrm{T}_{1}$ の位置 $\left[\mathrm{i}_{1}\right]$ に置いて○印であらわす。終点は時点 $\mathrm{T}_{2}$ の位置であ る。図示の実線は点 $\left[\mathrm{i}_{1}\right],\left[\mathrm{i}_{2}\right]$ を結んだもので平均移 動べクトルを示す。破線は $\mathrm{a}$ 点と結んだもので，誤差 を考慮した場合の移動量の最大值および平均移動方向 から右側への最大偏位を示す。点線は $\mathrm{c}$ 点と結んだも ので, 䛊差を考慮した場合の移動量の最小值と平均移 動方向から左側への最大偏位を示寸。なお, これら各 線の先端がベクトルの終点を示す。

移動べクトルを, XH 面, YH 面および $\mathrm{PH}$ 面(任意 方向の鉛直投影面）の上に投影した場合についても， これと同様の手順によって表示することができる。

\section{5-3 平面図上における地すべり挙動の解析}

前章で述べた57個の変位追跡点の XY 平面上の座 標平均值㧍よび平均二乗誤差のデー夕を, 前節の手法 で解析して図化した結果を図 4 に示す。

この図において, 中央部一帯の変位追跡点の移動量 は比較的大きく, 各点の移動方向にはほぼ共通した傾 向がみられる。しかしこれを取り囲む周辺部の変位追 跡点の移動べクトルは，大きさ，方向ともにかなり不 規則である。この研究では前者は地すべりによる地表 変状の顕著な地帯に, 後者はそこからかなり離れた地 帯に設置した変位追跡点であるため, 後者のバラツキ には写真測量の誤差が大きく影響している。

いまこの地すべりに関して図 4 から判定したい主要 な情報は次の 3 項目である。

1）個々の変位追跡点の移動の有無

2）平面移動特性から見た地すべりブロックの区分

3）地すべりブロックの移動方向と移動速度

\section{A）地表の移動の有無の判定}

個々の変位追跡点の移動の有無の判定には以下の手 順を用いた。

a ) 変位追跡点 $[\mathrm{i}]$ の移動量 $\mathrm{S}_{\mathrm{XY}}$ を式(9)で，これに

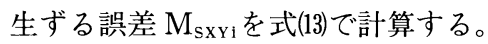

b ）移動量に対する誤差の割合（単位移動量に対す る誤差率） $\varepsilon_{\mathrm{XYi}}$ を次式で定義する。

$\varepsilon_{\mathrm{XY1}}=\mathrm{M}_{\mathrm{SXY1}} / \mathrm{S}_{\mathrm{XY1}}$

c )これより変位追跡点 $[\mathrm{i}]$ の移動量の重み $\mathrm{P}_{\mathrm{SXY}}$ を
次式で求める。

$\mathrm{p}_{\mathrm{SXY1}}=1 / \varepsilon_{\mathrm{XY1}}{ }^{2}$

d）各変位追跡点の重みを求めたのち, 全点からみ た場合の $\left[\mathrm{i}\right.$ ] 点の相対重量 $\mathrm{P}_{\mathrm{SXY}}$ を次式で算出する。

$\mathrm{P}_{\mathrm{SXY}}=\mathrm{p}_{\mathrm{SXY}} / \Sigma \mathrm{p}_{\mathrm{SXY1}}$

e ）変位追跡点 $[\mathrm{i}]$ の相対重量付き移動量 $\left[\mathrm{S}_{\mathrm{XY1}}\right]$ を 次式で求める。これを用いて再び四化を行なう。

$\left[\mathrm{S}_{\mathrm{XY}}\right]=\mathrm{P}_{\mathrm{XY} 1} \cdot \mathrm{S}_{\mathrm{XY1}} \mathrm{F}$ ( $\mathrm{F}$ は拡大率 $)$

(28)

この a ）～e）の演算処理を57個の全部の変位追跡 点に施した結果を図 5 に示す。各点のべクトルは平均 移動べクトルである。ベクトルの長さは式(28)で計算し た相対的なものである。またこの図には，現地の地形 の概要を記入した。

図 4 と図 5 に関する考察を以下に要約する。

(a) 図 4 ではほとんど全部の点が移動を示している。 これに上記の処理を施すと，明確な移動を示す点は 図 5 のように整理される。この図を用いて地すべり の生じている領域を平面図上で判定することができ る。

(b) 点52は広葉樹の頂部に追跡点を設定したものであ る。この点は他に比べて異常な動きを示す。これは 地すべりで樹木が傾きながら移動するためである。 したがってこのべクトルは地表の移動状況を正しく 示すものではないが, 地表の移動の有無の判定には 十分役立つ。

(C) 点47から点57までは樹上に設けた変位追跡点であ る。困 4 においてこれらのベクトルの方向誤差（実 線に対する破線と点線の開きの角度) は地表点（1 ～40）や荒地点 (41～46) に比べて大きい。これは 樹上点の計測誤差が他に比べて大きいことを意味す る。

(d) 図 5 における樹上点の相対重量付き移動べクトル は，点51と52以外は図示できないほど小さいため， 事実上消去されている。点52に関しては(bで述べた とおりである。点50のべクトルは図 4 では $96 \mathrm{~cm} の$ 平均移動量を示すが, 移動方向は周辺の点51, 31 , 45等に比べてかなりずれている。しかしこの点50の ベクトルは図 5 では消去されている。それはこの点 の座標計測誤差が大きいことによる。

(e) 点51の座標精度は樹上点の中では比較的高いため に，図 5 ではそのべクトルが表示されている。移動 方向は地上点33のそれとほぼ一致している。これは 樹上点51のベクトルの信頼度の指標といえる。しか 


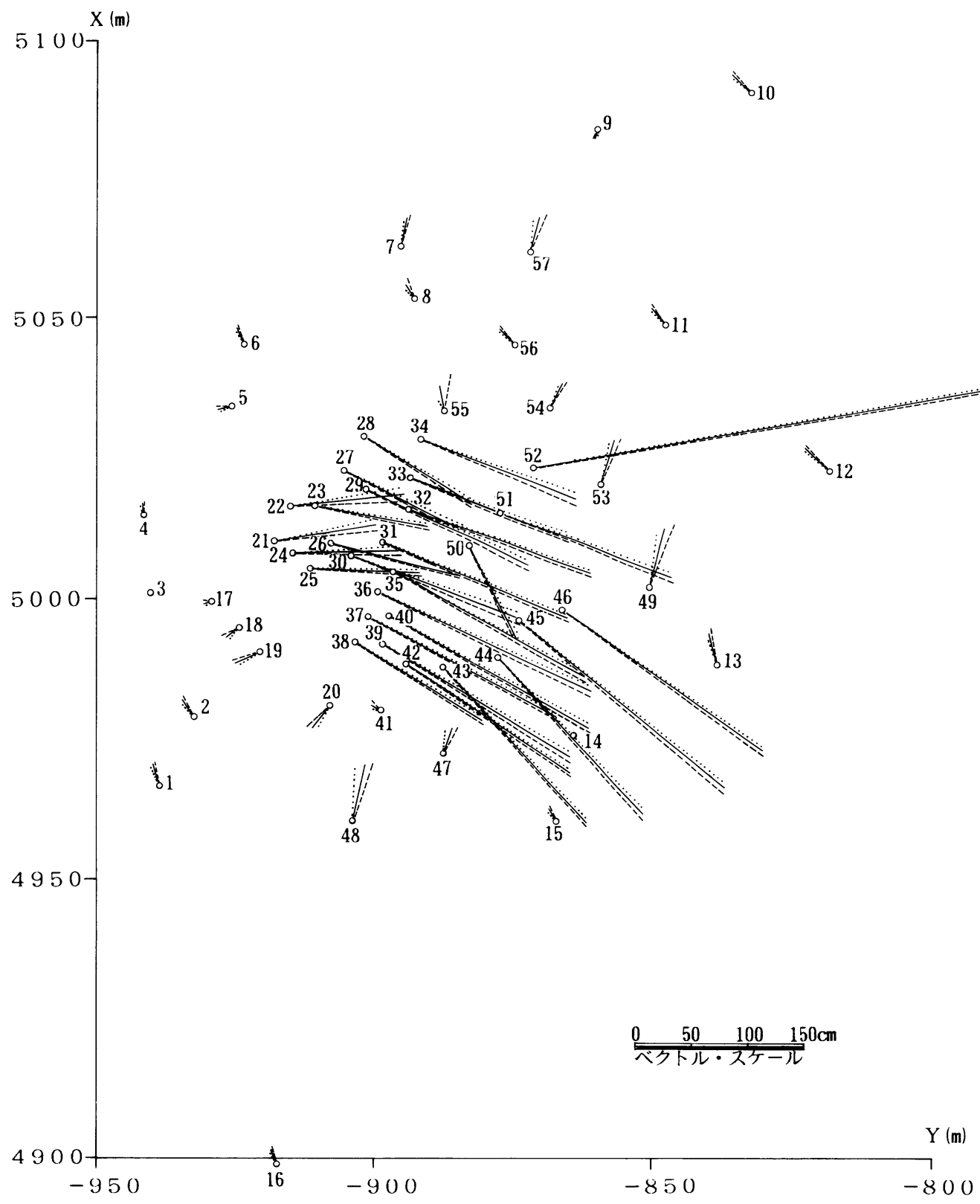

図 4 地すべク地とその周辺に設けた変位追跡点の水平移動べクトル

(長野市広瀬地区 891005 891010)

[実線は座標平均值から求めたべクトル 点線と破線は座標䛊差を考慮したベクトル]

しベクトルの長さについてみると, 図 4 では点 33 と 点51がほぼ同一であったものが，図 5 では点51が非 常に短かい。これは両者の座標計測誤差の程度に起 因するものである。

(f) 困 5 において，地すべり領域の周辺にあってべク
トルの表示されていない点の大部分は，不動または ほぼ不動と考えられる地物を変位追跡点としたもの である。したがって図 4 に示されるこれらの点のべ クトルは䛊差べクトルとみなすことができる ${ }^{\mathrm{C} 6)}$ 。 


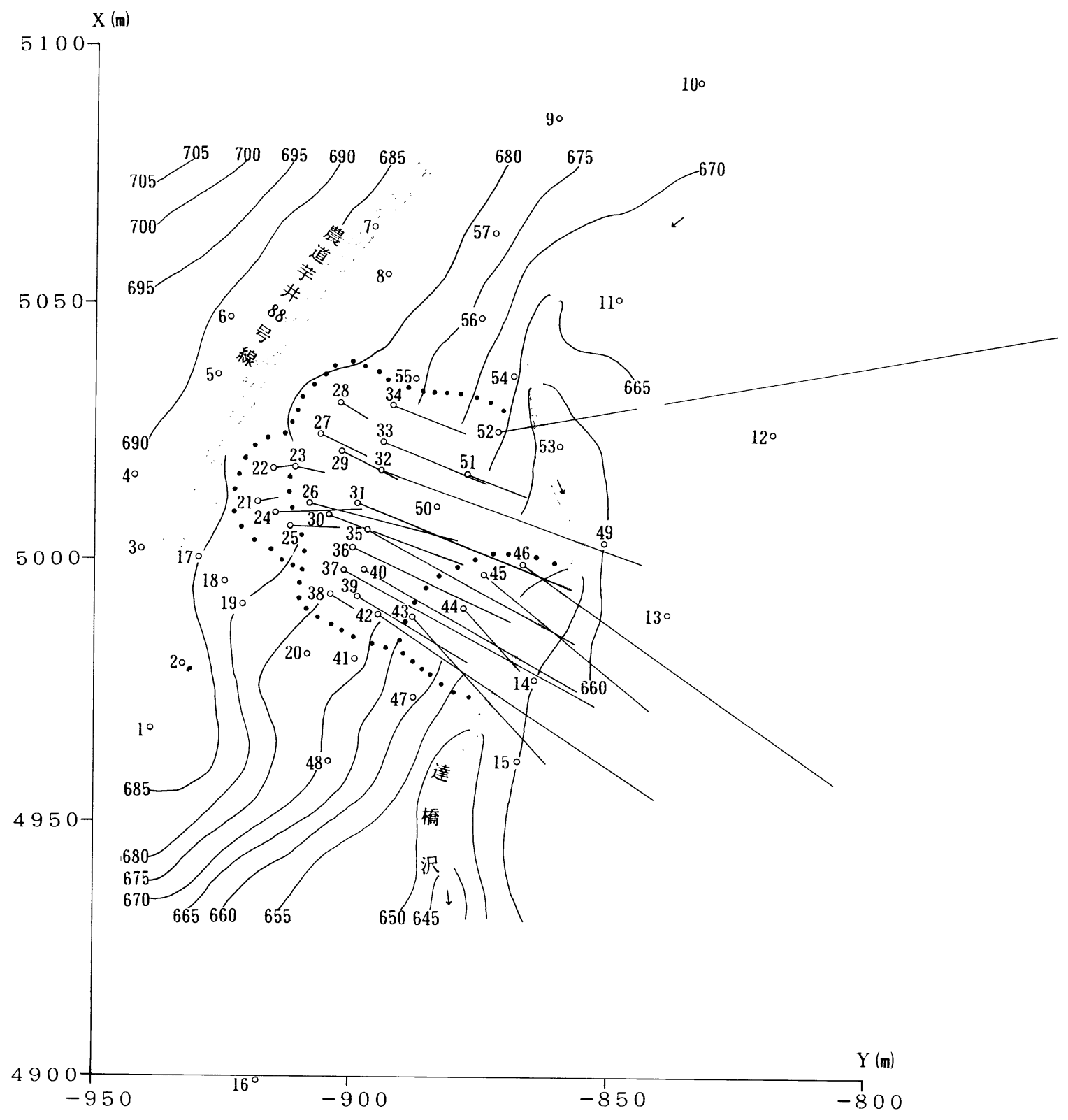

図 5 変位追跡点の重量付き水平移動ベクトルと地すべクブロックの推定

(長野市広瀬地区 891005 891010)

[点線は移動べクトルから推定した地すべりブロックの境界線]

\section{B）地すべクブロックの区分}

地すべりブロックとは，地下に発生したすべり面の 上をほぼ一体化して滑動する土石の集団のことであ る。地すべりブロックの大きさは，地すべりの規模や 破壊の進行の程度によってさまざまである。いま，U とつの地すべりブロックの上にいくつかの変位追跡点
C6）図4において，樹上点（点番号47以上）の誤差ベクト ルは他の諸点に比べてかなり大きい。誤差べクトルに 注目して地表点の精度の高いものから順位をつける と：コンクリート構造物の角(点 $3,5,16)$, 地表に放 置された物体の角 (点 $2,4,9,17,18,19)$, 裸地と草 地の境界部分（点 $6,7,11,13,18 ）$ となる。そして道 路側溝の屈曲点（10）や水田の畦道の屈曲点（12）の 精度は低い。 
がある場合，平面図上で各点が示す移動べクトルの間 にはつぎの $2 つ の$ 特徴が見られるはずである。

1）近接した変位追跡点の移動量はほぼ等しい。

2）移動方向はいずれの変位追跡点もほぼ等しい。 この 2 点に注目して図 4 と図 5 について各点のべク トルを判読すると, 次のような考察ができる。(図 5 の 点線は同図の移動べクトルから推定した地すべりブ ロックの境界線である。)

(a) 地すべり地の頭部には，時計回りに回転するよう な形で，この地すべりの主動ブロックに追従する小 さなブロックがある。点 $21 ， 22,24,25$ はこのブロッ クの上に存在する。点 23 点 26 のベクトル，この 小ブロックの移動に若干の回転が伴うことを示して いる。

(b) この地すべりの下方には, 主動ブロックによって 誘発されたとも考えられ中程度のブロックが存在す る。点 $43,44 ， 45 ， 46$ はこの中ブロックの頭部付近 に位置する。また逆の見方として，この地すべりは 最初に下方の中ブロックが動きだし，その影響で主 動ブロックが活動を始めたと考えることもできる。

(C) 図 5 においてべクトルの表示されている変位追跡 点の中で, 上記の (a) (b)で述べたもの以外の大部分 の点は, この地すべりの主動ブロックの上に存在す る。

\section{C ）地すべクブロックの移動方向と移動速度}

Uとつの変位追跡点の移動方向は, その点が図上で 示すべクトルの方であり, 移動速度はべクトルの長 さ (移動量) と観測期間（時間）との比である。

地すべりブロック上の多数の変位追跡点のベクトル に対しては，以下に示すような重み付き平均法でその ブロックの移動方向と移動量（速度）を求める。

変位追跡点 $[\mathrm{i}]$ の移動方向角 $\phi_{1}$ を, 式(7)の記号を用 いて次式で求める：

$$
\phi_{\mathrm{i}}=\tan ^{-1}\left(\Delta \mathrm{Y}_{\mathrm{i}} / \Delta \mathrm{X}_{\mathrm{i}}\right)
$$

この点のベクトルの移動方向の平均二乗誤差 $\mathrm{M}_{\mathrm{Cuvi}}$ を 式(21)で求め, 移動方向角の重み $\mathrm{p}_{\mathrm{CUvi}}$ を次式で求める：

$$
\mathrm{p}_{\mathrm{Cuvi}}=1 / \mathrm{M}_{\mathrm{Cuvi}}{ }^{2}
$$

これより当該ブロックの重み付き移動方向角 $[\phi]$ を次 式で計算する：

$$
[\phi]=\Sigma \mathrm{p}_{\mathrm{cUVi}} \cdot \phi_{\mathrm{i}} / \Sigma \mathrm{p}_{\mathrm{cuvi}}
$$

移動量（速度）は, 点 $[\mathrm{i}]$ の二次元移動量 $\mathrm{S}_{\mathrm{XYi}}$ を式 (9)で，その重み $\mathrm{p}_{\mathrm{SXY}}$ を式(26)で求めたのち, 次式で当該 ブロックの移動量 $\left[\mathrm{S}_{\mathrm{XY}}\right]$ を計算する :

$$
\left[\mathrm{S}_{\mathrm{XY}}\right]=\Sigma \mathrm{p}_{\mathrm{SXY}} \cdot \mathrm{S}_{\mathrm{XYi}} / \mathrm{\Sigma}_{\mathrm{SXYi}}
$$

\section{5-4 鉛直投影面上における地すべり挙動の解析}

地すべりの挙動を鉛直な投影面の上で解析する場合 は，解析用の投影面を注目するひとつの地すべりブ ロックの移動方向と平行に置き，その面上に変位追跡 点の移動軌跡を投影する。

いま, 地すべりブロックの移動方向角 $\phi$ が式(31)で与 えられているとき, XY 座標系の原点を通り, X軸から 右回りに測った角が $\phi$ となるように, 投影面の水平軸 （P軸）の正の方向を定める。

ここで変位追跡点 $\left[\mathrm{i}\right.$ ] の XY 座標值を $\mathrm{X}_{\mathrm{i}}, \mathrm{Y}_{\mathrm{i}}$ とす るとき,この点の $\mathrm{P}$ 軸上の座標值 $\mathrm{P}_{\mathrm{i}}$ は次式で与えられ る :

$$
\mathrm{P}_{\mathrm{i}}=\cos \phi \cdot \mathrm{X}_{1}+\sin \phi \cdot \mathrm{Y}_{1}
$$

この変換で座標值 $\mathrm{X}_{\mathrm{i}}, \mathrm{Y}_{\mathrm{i}}$ の平均二乗誤差 $\mathrm{m}_{\mathrm{Xi}}, \mathrm{m}_{\mathrm{Yi}}$ は $\mathrm{P}_{\mathrm{i}}$ に伝播する。 $\mathrm{P}_{\mathrm{i}}$ の誤差 $\mathrm{m}_{\mathrm{Pi}}$ は次式で与えられる：

$$
\mathrm{m}_{\mathrm{P} 1}{ }^{2}=\cos ^{2} \phi \cdot \mathrm{m}_{\mathrm{xi}}{ }^{2}+\sin ^{2} \phi \cdot \mathrm{m}_{\mathrm{Y} 1}{ }^{2}
$$

水平に $\mathrm{P}$ 軸, 鉛直に $\mathrm{H}$ 軸をとった $\mathrm{PH}$ 投影面の上に おける変位追跡点の移動べクトルに生ずる誤差の問題 に関しては, 座標值： $\mathrm{P}_{\mathrm{i}} \pm \mathrm{m}_{\mathrm{Pi}}, \mathrm{H}_{\mathrm{i}} \pm \mathrm{m}_{\mathrm{Hi}}$ を用いて5-2 に示したものと同様な手法を適用できる。よってここ ではその解析に関する記述を省略する。

困 6 に鉛直投影面上における解析の一例を示す。投 影面の方向角は： $\phi=80^{\circ}$ とした。この図に示した変位 追跡点は, 前節で座標值の重みを考慮して解析した際 に明確な移動の認められた点（図 5 でベクトルの表示 されている点）のみである。図示のベクトルは各測点 の $\mathrm{P}, \mathrm{H}$ 座標の平均値を用いて定めたものである。

困 6 において左端はほぼ地すべり地の頭部，右端は ほぼ脚部である。すなわち，点21，22，24等は地すべ $\eta$ 地の頭部, 点 $32,33,34$ 等は中部, 点 51,52 等は脚 部の付近に位置する変位追跡点である。特に点51と 52 は樹上点であるから，そのべクトルで地表の動きを推 定するためには，点の位置（標高(H)）を樹高（約 $15 \mathrm{~m}$ ) に相当する分だけ下方に移して観察する必要がある。

各変位追跡点のべクトルの傾きを図の左から右へ順 次にたどってみる(40番台の点は除く)。全体的な傾向 として, 左端では急な右下がりを示したべクトルの傾 きが徐々に緩くなり，右端に至ると右上りに転じてい ることが分かる。このことは，これらの変位追跡点を 載せた地すべり土塊がほぼ一体化して回転運動をして いることを意味する45)。このようなべクトルの軌跡を 


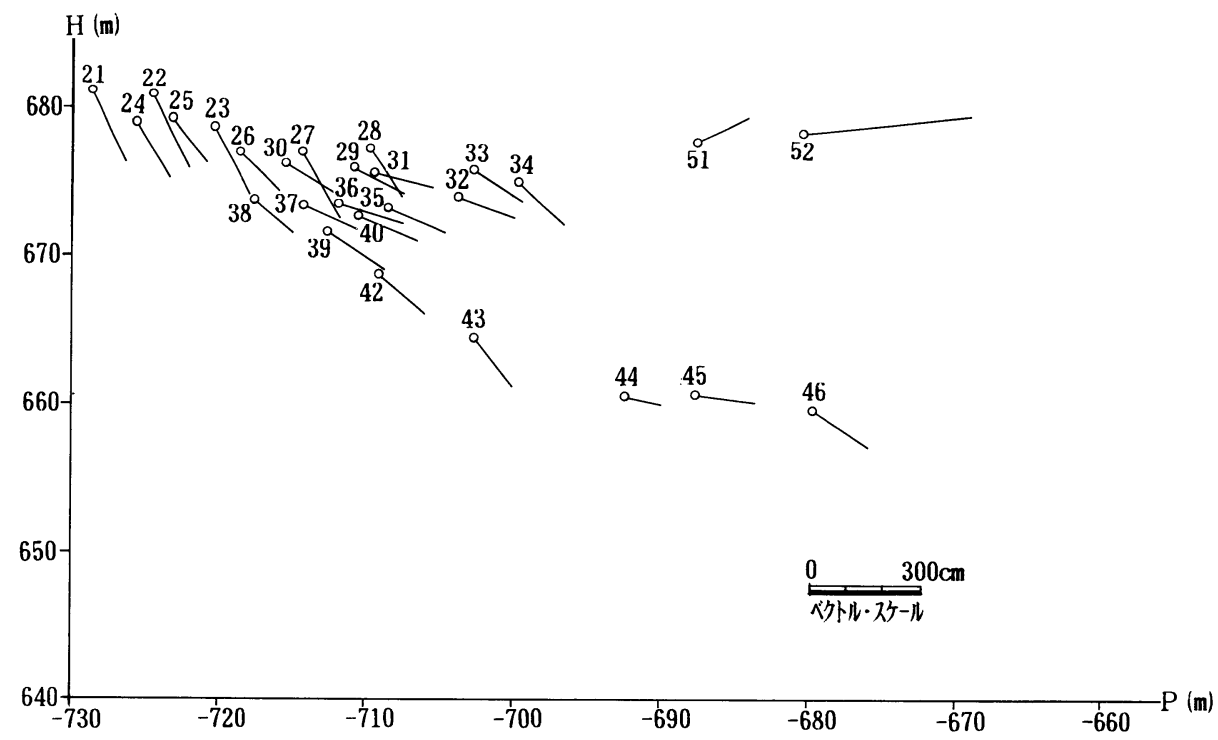

図 6 地すべク地内の变位追跡点の投影断面図上の移動べクトル [投影面方向角 $\left.=80^{\circ}\right]$ （長野市広瀬地区８91005～891010）［図５で移動が明確な点のみを表示］

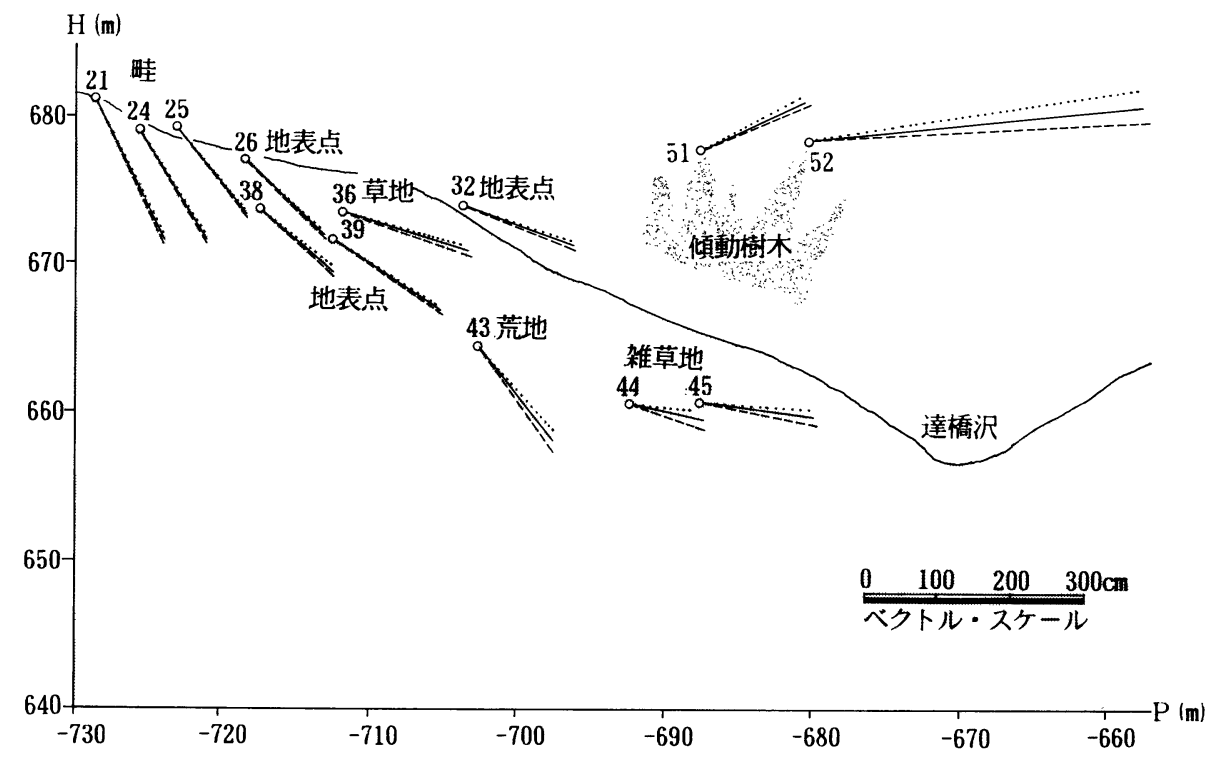

図 7 投影断面図 [投影面方向角 $=80^{\circ}$ ] 上における座標誤差を考慮した変位追跡点の移動ベクトル [実線は座標平均值から求めたべクトル＼cjkstart点線と破線は座標誤差を考慮したべクトル]

解析して地下のすべり面の位置と形状を推定すること ができる7)。

つぎに図 6 の40番台の変位追跡点のベクトルの傾き を左側の点から順次右側へと観察すると，この一帯に も上記のような回転運動の存在を推定できる。ただし 点46は地すべり地の末端部にあり，谷川に向かって滑
落しているため，ベクトルの勾配が急になっている。 このほかにも, ベクトルの勾配が点の位置とともに 漸変していく傾向が, 周辺と調和しない点がいくつか ある。その原因としては：1)投影面方向角が不適当で あること，2)変位追跡点が急斜面上にあり，そこに局 部的な表層滑落が生じていること，等が考えられる。 
また点52のべクトルの勾配が点51よりも緩やかなの は，樹木の傾動が原因となっている。

図 7 には図 6 に示した変位追跡点の中から若干の点 を選んで（図の混雑を避けるため） $\mathrm{P} ， \mathrm{H}$ 座標值の誤 差を考慮した場合のべクトルを示した。実線, 点線, 破線の区別は図 4 の場合と同様である。図示の断面形 状は点：X=5000m, $\mathrm{Y}=-950 \mathrm{~m}$ を通り $\mathrm{X}$ 軸と $80^{\circ}$ の 方向線で切った地形断面図である。樹木は傾動の状況 を概念的に示したものである。この図からつぎの考察 ができる。

（a）水田のあぜ（21，24，25）や，斜面上であっても 明瞭な物体 $(26,32,38,39)$ の上に変位追跡点を 設定した場合は精度がよい。

(b) 雑草の隙間から目標物を確認するような草地(36)や 荒地(43)に設けた変位追跡点の精度はよくない。

(C) 雑草の植生の境界（44，45）に変位追跡点を設定 した場合は，水平位置，標高ともに精度が下がる。

(d) 樹上点 $(51 ， 52)$ が示す移動べクトルの誤差は, 傾動する樹木(52)に対しては極めて大きくなる。

\section{6. 総 括}

地すべりが発生した場合，防災対策上直ちに必要と される情報は, 地すべり土塊の移動方向と移動速度, および地すべり変動の発生している範囲である。これ らの情報を得る手段は測量のみであり, 地形が複雑な 場合 ${ }^{6}$ とか現地立入が危険な場合8)にはその手法は空 中写真測量に限られる。

本研究は, 突発性の地すべりに対して, 対空標識を 用いずに写真測量を実施した場合，地すべりに関する 情報がどのような精度で得られるかに注目して実験的 な検討を試みたものである。研究を通じて知り得た事 項を以下に要約する。

(a) 撮影時点の異なる写真上で計測された地表目標点 の三次元座標値の間に, 測量誤差以上の差が認めら
れる場合，その点は移動していると判定できる。

(b) 移動量の検出精度は, 2 つの撮影時点の時間間隔 が長いほど向上する。しかし停止に近い地すべりに 対しては意味がない。よって最初の写真撮影は一刻 も早く実施することが大切なポイントである。

（）撮影時点の異なる両写真上で共通する地物を確認 し，変位追跡点を定めるためには，夕イポイントの 選点ブリックの手法を有効に利用できる。

(d) 写真上に選定した変位追跡点の座標值には，点の 移写，写真の標定，座標計測等による誤差が介入す る。

(e) 各変位追跡点の測定誤差から座標値の重みを求 め, この重みを付けて移動べクトルを算出すると, 各点の移動の有無をかなり正確に判定することがで きる。

(f) 移動ベクトルを平画図および投影断面図上に投影 して,地すべり挙動の特性を判読することができる。

\section{参 考 文 献}

1) 吉澤孝和：防災プロジェクトへの測量技術の応 用，応用測量論文集， $1-1$, pp. 21-28, 1990.

2) 吉澤孝和：奈良尾地すべり地における地すべり挙 動の精密測量とその解析, 地すべり, 15-3, pp. 1116, 1978 .

3 ）土屋智・大村寛: 斜面崩壊時刻の予測式とその力 学的特長に関する考察, 地すべり, 25-2, pp. 2-8, 1988.

4 ）吉澤孝和：多項式を用いた地すべり地の地下すべ ク面形状の推定, 地すべり，25-3，pp. 1-10，1988.

5 ）吉澤孝和：地上測量による地下すべり面形状およ び地すべり影響範囲の推定, 地すべり, 26-3, pp. 28-39, 1989.

6 ）打荻珠男：航空写真による地すべり状況の测定, 地すべり，5-2, pp. 27-33, 1968.

7 ）吉澤・他：空中写真测量による地すべり情報の提 供とすべり面の解析，地すべり，27-4.pp. 9-17, 1991.

8 ) 長岡正利：長野市地附山地すべりの災害状況と地 形変化, 測量, 35-10, pp. 23-31, 1985. 